DE DE GRUYTER OPEN

\section{Research Article}

(c) 2017 Galang Asmara This is an open access article licensed under the Creative Commons Attribution-NonCommercial-NoDerivs License (http://creativecommons.org/licenses/by-nc-nd/3.0/).

\title{
Strengthening Ombudsman Institutions of the Republic of Indonesia to Increase Protection of Citizens' Rights in Public Services
}

\author{
Galang Asmara
}

Lecturer of Faculty of Law, Mataram University, Indonesia

Doi: $10.1515 / m j s s-2017-0023$

\begin{abstract}
This paper aimed to identify and discuss the weaknesses of the ombudsman of the Republic of Indonesia and its strengthening efforts. To obtain the objectives, the authors conducted both normative and empirical study by studying various laws and documents related to the institution. The facts obtained were analyzed using juridical and qualitative analysis methods. The result showed various weaknesses in both juridical and empirical aspects. The juridical weakness can be seen from the legal basis for of Ombudsman which is still weak. The empirical weaknesses include: a. the lack of socialization of ombudsman institution of the Republic of Indonesia; $b$. ineffectiveness of the ombudsman recommendation; $c$. the lack of independence and impartiality of the ombudsman institution; and e. limited ombudsman institutions. To strengthen ombudsman institutions of the Republic of Indonesia, it is necessary to: a. include an Article in the 1945 Constitution which regulates the Ombudsman of the Republic of Indonesia; $b$. do continuous socialization efforts related to the function and procedure of public complaints to Ombudsman; c. provide strict supervision on the implementation of the Ombudsman's recommendations by the Ombudsman of the Republic of Indonesia as well as by the community; $d$. increase the commitment of the Ombudsman of the Republic of Indonesia to avoid interference of power aimed at influencing the performance of the Ombudsman of the Republic of Indonesia; and e. establish an Ombudsman in the districts and municipalities, especially those with maladministration cases.
\end{abstract}

Keywords: ombudsman institutions, protection of citizens' rights, public services

\section{Introduction}

The protection of citizens' rights against maladministration, especially in the framework of public service, is one of the necessities of a democratic constitutional state. Indonesia is a democratic State of Law. This can be known from several provisions in the 1945 Constitution of the State of the Republic of Indonesia.

The protection of the citizens' rights to maladministration becomes significant since maladministration is one of the actions of the government in public service that violates the rights of citizens and may cause physical, psychological, property, and potential damage to citizens. Therefore, the existence of an institution that serves to protect the rights of citizens from the act of maladministration is a requisite. One of the institutions that have the authority to provide protection for the rights of citizens against maladministration act is Ombudsman.

According Galang Asmara (2014:12) currently there are more than 170 countries in the world which have Ombudsman institutions with various names such as: Médiateur de la République (France), Parliamentary Commissioner for Administration (UK), Protecteur du Citoyen (South 
Africa), Volksanwaltschaft (Austria), Public Complaints Commission (Nigeria), Provedor de Justiça (Portugal), Difensore Civico (Italy), Investigator-General (Zambia), Citizen's Aide (lowa), Wafaqi Mohtasib (Pakistan), Lok Ayukta (India), and Tanod Bayan (Philippines).

Indonesia has established an Ombudsman institution since 2000, motivated by the wish of the Indonesians to establish an independent supervisory institution because the supervisory institutions at the moment were seen unable to show good performance. This is indicated by the rampant practices of corruption, collusion, and nepotism among government apparatus, including in the judiciary. On the other hand, public services carried out by the bureaucracy, either government bureaucracy or the courts are perceived further from justice and legal certainty.

Based on above description, the study focused on: What are the problems or weaknesses of the Ombudsman of the Republic of Indonesia and what efforts should be done to further strengthen the institution.

\section{Method}

This study aimed primarily to identify the weaknesses of the Ombudsman of the Republic of Indonesia and seek the best solution in order to strengthen the position and function of the institution. For this purpose, the authors conduct both normative and empirical study by studying the various legislation and various documents related to the institution and interviews with several relevant stakeholders. The various facts obtained were analyzed using normative and qualitative juridical analysis method.

\section{Discussion}

\subsection{Characteristics of Ombudsman Institutions in Indonesia}

The Ombudsman Institution in Indonesia is called the Ombudsman of the Republic of Indonesia (ORI) or known as Ombudsman. ORI or Ombudsman is regulated in Law Number 37 of 2008 on the Ombudsman of the Republic of Indonesia. Under the provisions of the Act, ORI is an independent state institution and does not have organic relationship with state institutions and other government agencies and in carrying out the duties and authority, it is free from other interferences of power (Article 2).

The existence of the Ombudsman is intended to: (a). realize a democratic, just, and prosperous legal state; (b). encourage effective, efficient, honest, open, clean, implementation of the state and government; (c). improve the quality of state services in all areas so that every citizen will gain equity, security, and better welfare; (d). help to create and improve efforts to eradicate and prevent maladministration, discrimination, collusion, corruption, and nepotism practices; (e). enhance the culture of national law, the awareness of community law, and the supremacy of the law of truth and justice (Article 4).

The Ombudsman of the Republic of Indonesia is located in the capital of the Republic of Indonesia with working territory covering all regions of the Republic of Indonesia. Therefore, Indonesia has solely one Ombudsman institution. However, if it is deemed necessary, the Ombudsman may establish an Ombudsman's representative in the province or district/city. The Ombudsman's representative has a hierarchical relationship with the Ombudsman of the Republic of Indonesia (Article 5).

Ombudsman of the Republic of Indonesia consists of 1 (one) chairman concurrently member; 1 (one) vice chairman concurrently member; and 7 (seven) members. They are all elected by the House of Representatives on the basis of nominees proposed by the President for a term of 5 (five) years and may be re-elected for only one (1) term of office. In carrying out its duties and authority, the Ombudsman is assisted by an assistant Ombudsman. Assistant Ombudsman is appointed or dismissed by the Chairman of the Ombudsman under the approval of a meeting of members of the Ombudsman. Also the Ombudsman is assisted by a secretariat headed by a Secretary-General, who is directly appointed and dismissed by the President.

The Ombudsman of the Republic of Indonesia has the main duty, among others, to receive 
the community report on the alleged Maladministration in the public service delivery, to conduct substantial examination of the report, and to follow up the Report. In performing the duties, the Ombudsman has the authority to complete the report through mediation and conciliation at the request of the parties, make recommendations concerning the report settlement, including recommendations to pay compensation and/or rehabilitation to the injured party. For the sake of the public interest, the Ombudsman is also authorized to announce the findings, conclusions, and recommendations. The Ombudsman is also authorized to make suggestions to the President, the head of the region, or other leaders of the State Organizer for the improvement of the organization and/or procedures of the public service. Other authorities of the Ombudsman are to advise the House of Representatives and/or the President, regional House of representative and/or the head of the region.

In order to carry out its duties and authority, the Ombudsman of the Republic of Indonesia shall be granted immunity, namely the right to be caught, arrested, interrogated, prosecuted, or sued in court (Article 10). Nevertheless, in checking the report, the Ombudsman shall be guided by the principle of independent, non-discriminatory, impartial, and free of charge. The Ombudsman shall listen to and consider the opinions of the parties and facilitate the reporting party in presenting the explanation. The Ombudsman in conducting the examination is also required to maintain confidentiality, except in the public interest. Obligation to maintain confidentiality for the Ombudsman does not even fall even though the Ombudsman stops or is discharged from office.

Who can be a reporting party of maladministration act to the Ombudsman is an Indonesian citizen. Whereas the reported party is a state and government organizer including those held by State-Owned Enterprises, Regional Government Enterprises, and State-Owned Legal Entities as well as private or individual agency assigned to perform certain public services part or all of whose funds are sourced from the State budget and expenditure and/or regional budget and expenditure budget.

\subsection{Some weaknesses of the Ombudsman of the Republic of Indonesia}

The result showed various facts that indicate the weakness of the Ombudsman of the Republic of Indonesia today, which are

a) A Weak Legal Basis

The existence of the Ombudsman of the Republic of Indonesia is currently based and regulated by Law No. 37 of 2008 on the Ombudsman of the Republic of Indonesia. In the hierarchy of legislation in Indonesia, the Act is under the Constitution and Provisions of People's Consultative Assembly. This means the existence of Ombudsman is still weak. Ombudsman is supposed to be regulated in the Constitution as there are in various countries in the world such as in the Netherlands, Sweden, Denmark Philipina, and others. If the Ombudsman is governed by the Constitution, the position of this institution will be very strong because it will be difficult to be dissolved since dissolving the Ombudsman means changing the Constitution. Meanwhile, to change the Constitution in the state administration system is very difficult compared with to change the Law. To amend the Constitution must go through the plenary session of the People's Consultative Assembly, while the proposed amendment to the Constitution can only be made by at least $2 / 3$ of the total members of the MPR and the decision is taken with the consent of at least $2 / 3$ of the number of members of the People's Consultative Assembly present (Article 37 of the 1945 Constitution). Whereas if the legal basis for the existence of the Ombudsman remains in the form of the Act, it is relatively easy to be dissolved because to change the Law in the Indonesian statehood system is sufficient through a trial in Parliament or by Decision of the Constitutional Court in the case of Judicial Review.

b) The Lack of Understanding of the Existence of the Ombudsman

The existence of the Ombudsman and how it works has not been fully known by the wider community. From the results of interviews with a number of public figures, academics, students, and ordinary people, it showed that most of them do not know about the existence of the Ombudsman. As many as $70 \%$ of respondents said not knowing what the 
Ombudsman of the Republic of Indonesia is. This is different from the existence of Police, Court, Attorney, KPK and others. 99\% respondents said they know these institutions. The nescience of the existence of the Ombudsman of the Republic of Indonesia by the public might be caused by its existence which is considered still new and less efforts of publications conducted by related parties.

c) The Lack of Effectiveness and Authority of Ombudsman Recommendations

Ombudsman's legal products are recommendations, including conclusions, opinions, and suggestions prepared by the Ombudsman based on the results of the investigation (Article 1 point 7 of Law No. 37 of 2008). Recommendation contains the settlement of report submitted by the community (the complainant) to the Ombudsman, including Recommendation to pay compensation and/or rehabilitation to the injured party.

The Ombudsman's recommendation should be submitted by the Ombudsman to the Reported Party's superiors to be implemented and/or followed up in order to improve the quality of good governance administration. According to Law Number 37 of 2008, the reported party and the reported party's superiors must perform the Ombudsman's recommendation. In the event that the reported party and the reported party's superiors do not implement the recommendation or only carry out part of the recommendations for unacceptable reasons to the Ombudsman, the Ombudsman may publish the Reported Party's superiors who do not implement recommendations and submit reports to the House of Representatives and the President. The Reported Party and the superior of the Reported Party violating such provision shall be subject to administrative sanction in accordance with the provisions of the law (See Articles 39 and Law No. 37 of 2008).

The result showed that the effectiveness of Ombudsman's recommendation is indicated still less, seen from the lack of participation of the reporting party to voluntarily implement the Ombudsman's recommendations. This is evident from the presence of reported parties or supervisors who do not want to implement the recommendations of Ombudsman. It appeared in Wijuyanto's arrest by the Police. In that case, the Ombudsman of the Republic of Indonesia (ORI) found a number of maladministration by the police. The Ombudsman issued four recommendations to the Chief of Police. However, none of these recommendations has been implemented by the National Police, even reported if the police officers who did maladminsitration were in promotion of position. Another indication is in the case of Mayor of Depo, in which the Minister of Public Works and the Mayor of Depok have ignored the settlement of Cinere-Jagorawi Toll-Free (Cijago), followed by the non-implementation of the recommendation of the Ombudsman of the Republic of Indonesia in the case of maladministration on the land acquisition process of people affected by the construction of the Cijago Depok toll road. Ombudsman's recommendation to the Minister for Housing and Public Works and the Mayor of Depok with No. 009/REK/0757.2012/PBP-08-50/T.6/VII/2001 was issued on July 11, 2014, but recently most Ombudsman's recommendation has not been implemented. This shows the lack of awareness of state organizers in complying with the Ombudsman's recommendations. It also shows that the authority of the Ombudsman's recommendation in the eyes of public officials or state officials is lacking.

d) Not Guaranteed Independence and Impartiality of The Ombudsman

Article 2 of Law No. 37 of 2008 stated that the Ombudsman is a state institution which is independent and does not have organic relationship with state agencies and other government agencies and in carrying out its duties and authorities is free from interference by other powers. The independence and impartiality of Ombudsman of the Republic of Indonesia as regulated in Article 2 of Law No. 37 of 2008 is currently questionable because Case Report of Novel Baswedan remains unclear while the case has been Given recommendations by the Ombudsman. The Ombudsman also does not take any action as requested by Law No. 37 of 2008. According to the Act, the Ombudsman may request information from the reported party and/or the superiors and conduct field checks to ensure the implementation of recommendation. In the event that reported party and the superiors do not implement the recommendation or only implement part of the 
recommendation for reasons which cannot be received by the Ombudsman, the Ombudsman can publish the head of the reported party that do not implement the recommendation and submit a report to the House of Representatives and the President (see Article 38; reported party and the superiors in violation of the provisions referred to Article 38 shall be liable to administrative sanctions in accordance with the provisions of laws and regulations (see Article 39).

In the absence of the actions carried out by the Ombudsman, as expected by the Law on the Ombudsman to report cases of Baswedan, it indicates the intervention of the authorities to the Ombudsman, which is the absence of follow-up of the case which might be unprofitable for the government.

e) The Lack Number of Ombudsman Institutions

f) Article 43 of Law No. 38 of 2007 states that where deemed necessary, the Ombudsman may establish an Ombudsman's representative in the province or district/city. At this time, almost all provinces already have Ombudsman's representative. However, regional Ombudsman representative has not been formed. The number of districts/cities in Indonesia is ....... Given the topography of the Indonesian territory consisting of islands which might cause the distance between Capital Provincial and District levels is far apart, regional Ombudsman representative should be formed. In addition, large number of occupations and poor public services currently require more Ombudsman.

\subsection{Efforts to Strengthen the Ombudsman of the Republic of Indonesia}

In order to strengthen the Ombudsman of the Republic of Indonesia, the following efforts should be undertaken:

a) Strengthening the legal basis of the Ombudsman of the Republic of Indonesia

The current Ombudsman of the Republic of Indonesia is governed by the Constitution. As a vital state institution, it should also be regulated in the Constitution. It is important that this institution has a strong position in the constitutional system of the Republic of Indonesia and has great authority. To strengthen the existence of the Ombudsman of the Republic of Indonesia, the first and main effort is to include articles that regulate the existence of the Ombudsman of the Republic of Indonesia in the Constitution. With the regulation of the Ombudsman in the 1945 Constitution, this institution's status will be permanent state institution and difficult to be challenged unless this institution will get a more adequate budget. In this connection, it needs political commitment from the representatives of the people who sit in parliament to propose a change of the Constitution to include provisions on the Ombudsman in the Constitution. In addition, the support of the community, especially academics, legal practitioners, and the press is also deemed strongly necessary.

b) Community participation in supporting the implementation of tasks and functions of the Ombudsman is very important. But such participation is impossible to grow when society is not familiar with this institution, whether it is related to the position, duties and functions and its benefits to society, nation, and state. If the public is not familiar with the Ombudsman, the public cannot be expected to report the government's maladministration actions in the public service. Therefore, the second attempt to strengthen the existence of Ombudsman institutions is to conduct socialization efforts to the community through various means, such as printed and electronic mass media, seminars, workshops, clinics complaints, talk shows, interactive dialogues, workshops, public lectures, etc. Socialization can also be done through the week of Ombudsman Complaint, public dialogue through mass media, etc.

c) Indepenedence and impartiality of the Ombudsman must be guaranteed by law and its implementation must be respected by all parties. When independence and impartiality are not implemented, Ombudsman will be barren. The successful implementation of the duties and authority of the Ombudsman depends solely on the institutional commitment to the independence and impartiality of the Ombudsman. In this regard, the third attempt to 
strengthen this organization is to build the commitment and stakeholders of both Ombudsman members and Ombudsman's assistants to respect and honor the independence and impartiality of the institution by avoiding deeds that may interfere with independence and impartiality.

d) The measure of the success of the National Ombudsman Commission's performance is determined by internal and external factors. Internal factors include: (1) the performance of the National Ombudsman Commission from the process of handling reports up to the stages of giving weighted opinions or recommendations to the authorized institution; (2) the spirit and commitment of leaders and staff and all Ombudsman to perform their duties and responsibilities respectively as mandated by the Law. On the other hand, external factors are related to: (1) response of the reporting agency for clarification/recommendation issued by the National Ombudsman Commission. The response depends on the strong willingness of the relevant officials/agencies to improve the conditions or problems voiced by the National Ombudsman Commission and the willingness to improve its performance in providing services to the community; (2) participation and the existence of the community to submit a complaint over the maladministration in public service carried out by the state organizers. If the community is indifferent, ombudsman undoubtedly undergoes difficulties to detect the occurrence of maladministration. In this connection, the strategic effort that needs to be done in order to strengthen the Ombudsman of the Republic of Indonesia is to motivate the public to know or experience any maladministration actions carried out by the government in the public service so as not to hesitate to report to the Ombudsman. On the other hand, the Ombudsman of the Republic of Indonesia must continually improve its work, strengthen its commitment, and improve the quality of its recommendations. It is important to create public confidence in the institution of the Ombudsman and to build an opinion that the Ombudsman is essential to the life of the nation and the state.

e) Due to limited number of Ombudsman in Indonesia, it is significant to establish an ombudsman representative institution in the region in order to strengthen the Ombudsman of the Republic of Indonesia.

\section{Conclusions}

The result can be concluded that there are various weaknesses of the Ombudsman of the Republic of Indonesia at this time either in juridical or empirical aspects. The juridical weakness can be seen from the legal basis for of Ombudsman which is still weak. The empirical weaknesses include: the lack of socialization of ombudsman institution of the Republic of Indonesia; ineffectiveness of the ombudsman recommendation; the lack of independence and impartiality of the ombudsman institution; and limited ombudsman institutions. To strengthen ombudsman institutions of the Republic of Indonesia, it is necessary to include an Article in the 1945 Constitution which regulates the Ombudsman of the Republic of Indonesia, do continuous socialization efforts related to the function and procedure of public complaints to Ombudsman, provide strict supervision on the implementation of the Ombudsman's recommendations by the Ombudsman of the Republic of Indonesia as well as by the community, increase the commitment of the Ombudsman of the Republic of Indonesia to avoid interference of power aimed at influencing the performance of the Ombudsman of the Republic of Indonesia, and establish an Ombudsman in the districts and municipalities, especially those with maladministration cases.

\section{References}

Asmara, G. (2014). The position of the Ombudsman of the Republic of Indonesia in the System of the Republic of Indonesia., LaksBang. Yogyakarta.

Muchsan. (1981). Introduction to Administrative Law. Liberty. Yogyakarta. 1981.

Roy and Philip Giddings. (2000). The Ombudsman Institution: Grouth and Development; in Roy Gregory and Philip Giddings (ed). Righting Wrongs, The Ombudsman in Six Continents. IOS Press. Amsterdam.

Sujata, A. (2000). Prospect Effectiveness of National Ombudsman Commission. Paper presented at seminar 
entitled "The Role of National Ombudsman Commission in Improving Good Governance". Jakarta.

Sujata, Antonius et al. (2002). Indonesian Ombudsman, Past, Present and Future, National Ombudsman Commission. Jakarta.

Surachman, R.M. and Sujata, A. (2000). The Indonesian Ombudsman amidst the International Ombudsman. Paper is presented at the Ombudsman Workshop. Jakarta.

Law No. 37 of 2008 on the Ombudsman of the Republic of Indonesia, State Gazette of the Republic of Indonesia Year 2008 Number 139.

Presidential Decree No. 44/2000 on the National Ombudsman Commission. 